DOI: 10.17805/ggz.2021.3.6

\title{
Культурная социализация молодежи в досуговой деятельности: особенности и основные тренды в XXI в."
}

М. А. Коленькова

Московский гуманитарный университет

В статье рассматривается досуговая деятельность как средство культурной сочиализации, описань особенности досуговой деятельности молодежи в ХХІ в.

Ключевые слова: культурная сочиализачия; сочииализация молодежи; соииализация; досуг; досуговая деятельность; досуг молодежи; социализация молодежи

\section{Cultural Socialization of Youth in Leisure Activities: Features and Main Trends in the 21st Century \\ M. A. Kolenkova \\ Moscow University for the Humanities}

The article examines leisure activities as a means of cultural socialization and describes the features of leisure activities of young people in the 21st century.

Keywords: cultural socialization; socialization of youth; socialization; leisure; leisure activities; leisure of youth; socialization of youth

\section{ВВЕДЕНИЕ}

Принято считать, что успешная социализация личности означает, что человек принят и интегрирован в социальное пространство общества. В настоящее время много говорится о разных видах социализации: политической, гражданской, гендерной, профессиональной и др. Подобное разветвление термина «социализация» в настоящее время подчеркивает сложность тех общественных процессов, которые влияют на индивида с самого рождения и до конца жизни.

Культурная социализация интегрирует индивида в культурное пространство общества, позволяет ему функционировать там через усвоение культурных норм, ценностей, форм поведения, установок, способов организации досуга и, в конечном итоге, формирует культурную картину мира.

\footnotetext{
* Статья подготовлена на основе доклада, представленного на IV Общероссийской (национальной) научной конференции «Моисеевские чтения» (Московский гуманитарный университет, 15-16 апреля 2021 г.).
} 
В молодежной социальной группе успешная социализация личности это также умение распознать вовремя свои способности и реализовать их. При неэффективной социализации личность чувствует себя отстраненной от жизни, отсталой, «чужой».

При этом молодежь - это такая социальная группа, которая характеризуется повышенной проблемностью в вопросе культурной социализации. Особенность процесса социализации молодежи заключается в завершении первичной социализации, выходом из семьи и началом вторичной социализации (Ковалева, 2017). К ее специфике относится и переход «от преимущественного свойства быть объектом социализации к преимущественному свойству быть субъектом социальной деятельности...» (Ковалева, Луков, 1999: 150).

\section{ДОСУГ И КУЛЬТУРНАЯ \\ СОЦИАЛИЗАЦИЯ МОЛОДЕЖИ}

Среди множества институтов социализации личности молодого человека досуговую деятельность среди прочих можно выделить как одну из важнейших. В процессе досуговой деятельности молодежь узнает (либо укрепляет, либо трансформирует) общественные идеалы, мировоззренческие, нравственные ценности, без которых не может состояться общественная жизнь. Досуг у молодежи представлен как важнейшая форма культурной социализации еще и потому, что в досуге особенно интенсивно реализуется механизм социализации, связанный с взаимодействием трех сфер: деятельности, общения и самосознания. Часто подросток только через досуговую деятельность имеет возможность актуализировать собственную личность через общение с внешним миром. Как отметила Г. М. Андреева, «впечатления, которые возникают при этом, играют важную регулятивную роль в процессе общения. Во-первых, потому, что, познавая другого, формируется и сам познающий индивид. Во-вторых... от меры точности "прочтения" другого человека зависит успех организации с ним согласованных действий» (Андреева, 1980: 142).

Досуговая деятельность является частью личной жизни молодого человека, это своеобразный микромир, который отражает культурную социализацию личности посредством индивидуального и творческого преобразования социальных норм и ценностей в личную систему смысложизненных ориентиров (Пак, 2008).

В последнее время отношение человека к досуговой деятельности в корне изменилось. Досуг представляет собой важнейшее средство оптимизации социокультурной сферы человека. Социализирующий потенциал сферы досуга затрагивает абсолютно все сферы жизни человека. Досуговая деятель- 
ность сама по себе является исключительно социальной деятельностью. Именно досуг знакомит с искусством, трудом, природой, культурами, правилами общения, эстетическими и нравственными ценностями.

Социализация в досуговой деятельности происходит в так называемой «досуговой среде», в которой оказывают влияние на личность факторы макро- и микросреды (Мудрик, 2011). Ценности макросреды - это ценности эпохи, государства, социума и культуры, а ценности микросреды - это ценности досуга, вуза, досуговых практик семьи, различных учреждений и сообществ. Последние имеют наиболее тесную связь с индивидуальностью личности.

Являясь самой по себе исключительно социальной деятельностью, досуговая деятельность отражена в сложившихся социальных трендах в XXI в.:

1. С социологической точки зрения, условия досуговой среды - это не только общественное устройство, экономические факторы, но и личный вклад каждого человека в свою жизнь, индивидуальное ее наполнение. Если профессиональная деятельность не всегда предоставляет широкую возможность выбора действий, то вариативность действий в досуговой деятельности ограничена лишь ценностными ориентациями самой личности.

2. Трудовая / учебная деятельность зачастую отходит на второй план и выступает только как источник средств для проведения свободного времени. Молодежь по сравнению с другими социальными группами отличается прогрессивностью, высоким потенциалом для общества и обладает достаточным количеством свободного времени, что делает их потенциально активными пользователями досугового пространства.

3. На досуговую деятельность молодежи оказывают большое влияние в первую очередь такие социальные институты как средства массовой информации и непосредственно сам институт досуга, предлагающий набор соответствующих практик. Они служат важными средствами формирования гражданского сознания и поведения людей.

4. Досуг сегодня сильно коммерциализирован, хотя материальный доход большинства молодых людей является низким либо отсутствует вовсе. Конкретные результаты опроса учащихся в вузах показали, что студенты не вовлечены в научную и творческую деятельность и не уделяют ей внимания. Стремление разнообразить досуг часто упирается в проблемы временного или материального характера. Также причиной пассивного досуга студентов часто становятся неорганизованный образ жизни и усталость. Подавляющее большинство студентов тратят свободное время на просмотр видеороликов в Интернете, телепередач, интернет-серфинг.

5. Молодежный городской досуг является скорее домашним. Несмотря на досуговые предложения студенты достаточно редко включены в него. 
Высокая степень медийного типа досуга среди студентов породила особую среду молодежного досуга, моду на использование гаджетов (смартфоны, планшеты) и определенный стиль общения, опосредованный этими устройствами. Развитие информационно-компьютерных технологий вытесняет такие традиционные формы проведения досуга как чтение литературы и живое общение с друзьями. Распространение и пропаганда потребительского жизненного стиля моделирует поведение, направленное на постоянную гонку за новомодными вещами, зачастую провоцируя нездоровое отношение к культуре, личности, знаниям, природе.

6. Ценности традиционной семьи играют все меньшую роль, несмотря на сохранение их значения для детей. В связи с этим досуг молодежи часто находится в отрыве от досуга родителей. Многие родители уделяют мало времени досугу своих детей.

7. Сегодня молодежь считает свои действия в досуге инвестициями в будущее. Учебная деятельность для студентов - это возможность достичь качественно нового уровня жизни и профессионального мастерства. Творческая досуговая активность в свободное от учебы время - это, прежде всего, личностное развитие, формирование человеческого стержня, активной жизненной позиции, душевного удовлетворения, а также определение своего места в обществе.

Рекомендации по улучшению социализационных возможностей досуговой среды включают не только мероприятия по улучшению инфраструктурных условий, но и работу в более глубинной мотивационной сфере человеческого сознания, которая заключается в адаптации молодежи к трансформационным процессам в обществе. Социализирующий контекст досуговой деятельности в условиях модернизационной политики общества заключается в преодолении дисфункций, связанных с проблемами переходного периода. Социализация в досуговой деятельности на таком этапе общества призвана способствовать самосохранению нации посредством воспроизводства традиций, образцов поведения и сбережения национального достояния.

\section{ЗАКЛЮЧЕНИЕ}

Основными механизмами культурной социализации молодежи через досуговую деятельность являются организация и самоорганизация досуга молодежи: традиционный (влияние через семью и микросоциальное окружение), институциональный (влияние через образование и другие институты общества), стилизированный (влияние через субкультуры), межличностный (влияние через значимых лиц), рефлексивный (индивидуальное переживание и осознание). 
Развитие социальной работы, государственной политики в досуге молодежи призваны минимизировать негативные тенденции, особенно развитые в городе, например, склонность молодежи к самоизоляции, слабую включенность в общественную, политическую и духовную жизнь. Девиантное поведение молодежи зачастую является следствием нарушений процесса социализации. Нередко коррекция молодежного поведения возможна только вовлечением в культурно-досуговую деятельность. В свое свободное время молодежь наиболее открыта для влияния и взаимодействия через различные социальные институты. Это дает возможность максимально эффективно воздействовать на их моральный облик и гражданское мировоззрение.

\section{СПИСОК ЛИТЕРАТУРЫ}

Андреева, Г. М. (1980) Социальная психология. М. : Изд-во Моск. унта. $416 \mathrm{c}$.

Ковалева, А. И. (2017) Проблемы социализации личности студента в вузе // Знание. Понимание. Умение. № 3. С. 48-62. DOI: 10.17805/zpu.2017. $\underline{3.4}$

Ковалева, А. И., Луков, В. А. (1999) Социология молодежи: теоретические вопросы. М. : Социум. $351 \mathrm{c.}$

Мудрик, А. В. (2011) Социализация человека : учеб. пособие для студ. высш. учеб. заведений. 3-е изд., испр. и доп. М. : Изд-во Моск. психологосоциального ин-та ; Воронеж : Изд-во НПО «МОДЭК». 623 с.

Пак, Л. Г. (2008) Социализация студенческой молодежи в социокультурном контексте // Социально-гуманитарные знания. № 4. С. 163-169.

Дата поступления: 23.04.2021 2.

\section{REFERENCES}

Andreeva, G. M. (1980) Sotsial'naia psikhologiia [Social psychology]. Moscow : Moscow State University Publ. 416 p. (In Russ.).

Kovaleva, A. I. (2017) Problemy sotsializatsii lichnosti studenta v vuze [Problems of a student's personality socialization at university]. Znanie. Ponimanie. Umenie, no. 3, pp. 48-62. (In Russ.). DOI: 10.17805/zpu.2017.3.4

Kovaleva, A. I. and Lukov, V. A. (1999) Sotsiologiia molodezhi: teoreticheskie voprosy [The sociology of youth: The theoretical issues]. Moscow : Sotsium Publ. 351 p. (In Russ.).

Mudrik, A. V. (2011) Sotsializatsiia cheloveka [Socialization of the person] : A guide for students of higher education institutions. 3rd edn., revised and enlarged. Moscow : Moscow Psychological and Social Institute Publ. ; Voronezh : NPO MODEK Publ. 623 p. (In Russ.). 
Pak, L. G. (2008) Sotsializatsiia studencheskoi molodezhi v sotsiokul'turnom kontekste [Socialization of student youth in a sociocultural context]. Sotsial'no-gumanitarnye znaniia, no. 4, pp. 163-169. (In Russ.).

Submission date: 23.04.2021.

Коленькова Мария Алексеевна - специалист учебно-методического управления Московского гуманитарного университета. Адрес: 111395, Россия, г. Москва, ул. Юности, 5. Тел.: +7 (926) 258-25-00. Эл. адрес: mariya.rus @ bbk.ru. Научный руководитель - Антонина Ивановна Ковалева, доктор социологических наук, профессор, заведующий кафедрой философии, социологии и культурологии Московского гуманитарного университета.

KOLENKOVA Maria Alekseevna, Specialist, Educational and Methodological Department, Moscow University for the Humanities. Postal address: 5 Yunosti St., 111395 Moscow, Russian Federation. Tel.: +7 (926) 258-25-00. E-mail: mariya.rus@bk.ru. Research adviser: Antonina I. Kovaleva, Doctor of Sociology, Professor, Head, Department of Philosophy, Sociology and Culturology, Moscow University for the Humanities.

Для цитирования:

Коленькова М. А. Культурная социализация молодежи в досуговой деятельности: особенности и основные тренды в XXI в. [Электронный ресурс] // Горизонты гуманитарного знания. 2021. № 3. C. 45-50. URL: https://journals. mosgu.ru/ggz/article/view/1453 (дата обращения: дд.мм.гггг). DOI: $\underline{10.17805 /}$ ggz.2021.3.6 